\title{
WOMEN ON BOARD AND CORPORATE SOCIAL RESPONSIBILITY (CSR) SPENDING ON EDUCATION AND INFORMATION COMMUNICATION TECHNOLOGIES (ICT)
}

\author{
Omotola Ezenwoke, Oluwatosin Esan, Williams Tion, Temiloluwa Adeyanju \\ Department of Accounting, Covenant University (NIGERIA)
}

\begin{abstract}
In developing economies, there are still largely unaddressed gaps on the quality of education and information technology alignment compared to the rest of the world. The authenticity of corporate responsibilities to social and economic challenges were more evident due to the Coronavirus recrudescent. The study seeks to assess whether women representation on board is pivotal to corporate social responsibility spending on education and Information Technology prior covid-19. Data on listed financial firms over the period of 2016-2019 was explored. We find significant and positive evidence that board with more than one woman are involved in educational CSR activities than board with no woman. Also, female representation on board has more effects when they are at least three. The effect of women on board is negative and significant when it comes to participation in CSR activities on ICT. Women to directors' ratio is one to four in a best-case scenario. The representation of women as CEOs is still not balanced. Also, having a female as the CEO do not significantly contribute to CSR spending on education and ICT. Board size is positively and significant to CSR spending on education and ICT. We conclude that greater numeric presence of women on board and not just a scanty representation is fundamental to CSR spending on education.
\end{abstract}

Keywords: Education, Information communication Technologies, Women, Gender, Corporate Social Responsibility, developing economics. Coronavirus, COVID 19.

\section{INTRODUCTION}

The quality of education and information technology alignment in developing economies compared to the rest of the world are still obvious. For instance, the world bank group puts learning poverty in lowand middle-income countries at $53 \%$, while $80 \%$ for the poorest countries [1]. It is envisaged that learning poverty can lead to loss in human capital and weakened economic opportunities in the long run. In addition, $35 \%$ of the population in developing countries has Internet access, compared to around $80 \%$ in advanced economies. [2].

Beyond economic responsibility, corporates are also obligated to the society. Corporations are expected to respond positively to societal needs and those that do not respond favourably are being called-out. It's being argued that socially responsible firms are more valuable to the society, while they outperform their counterparts in business reputation financial performance and growth [3]-[5]. However, the choice on obligation to the public is largely dependent on upper echelons attributes. These attributes include gender, personality, experience and education. Gender, being attribute of focus has gained a lot of attention in recent times. In fact, gender socialization theory offers an explanation on how gender roles are internalized from the onset of human life thus resulting in gender differences. It is suggested that certain traits such as kindness, empathy, interpersonal sensitivity are more noticeable in women [6], [7]. These traits are likely to reflect in female leadership role, thereby leading to heterogeneity in a corporate decision-making [8], [9].

Corporate Social Responsibility (CSR) theorised obligations extended to stakeholders beyond shareholders. Previous research indicates that females are more sensitive to the needs of various stakeholders due to their kind, expressive and concern for others features [10], [11]. Thus, it is more likely that female directors are involved in CSR activities [12], [13]. However, gender differences in behaviour alone may not necessarily lead to female directors having an impact because they tend to be under represented on the board [14]. Increase in female directors from a minimal existence to constitute a critical mass have more effects on firm outcome [15]. Specifically, significant financial improvement occurs when companies move from having one to two female directors [8], [16].

The need for adequate female representation on board has gained attention in literature and in the media. First, corporations are under regulatory pressure or requirement to increase female 
representation on board [15]. Second, the Sustainable development goal 5 of the United nations sets out to attain gender fairness and to empower all women. Third, women representation on board is recognised as good corporate governance practice as this results in positive corporate outcomes [17]. However, in empirical literature there are mixed results on the effects of women on corporate board. For instance, women presence on board is related to greater corporate innovation success [18]. Also, women on board are influential in disclosing corporate and social activities [19]. Contrary, female director do not matter in improving firm performance [20]. In this respect, gender differences are still being explored on its role in board room engagement. The question as to why women representation on board is so important.

The research attempts to explore these dynamics by studying the effects women representation determine the election of CSR spending on Education and Technology. We contribute to literature by providing evidence from a major emerging market. First, we present empirical evidence on the relationship between number of female representations on board and choice of CSR spending on Education and ICT. Second, we checked for the likelihood effects of the number of females on board in determining CSR Spending on Education and ICT using a board without no female as a reference. To this end we predict the following hypotheses

$\mathrm{H}_{1}$ The proportion of women on board is positively influential to CSR spending on educational activities

$\mathrm{H}_{2}$ The proportion of women on board is positively influential to CSR spending on ICT activities

$\mathrm{H}_{3} \quad$ A board with more than one woman is more likely to be involved corporate CSR spending on educational activities than a board with no woman.

$\mathrm{H}_{4} \quad$ A board with more than one woman is more likely to be involved corporate CSR spending on ICT activities than a board with no woman.

The remaining part of the paper is structured as follows. In the next section, we describe our method. thereafter, we present our results. In section 4 , we conclude.

\section{METHODOLOGY}

We obtained data from the annual reports of financial firms listed on the Nigerian Stock Exchange. Our sample comprises 151 observations of 49 firms between 2016-2019 after excluding firms with incomplete data. The financial firms were the focus of our research due to the viability of the firms in the Nigerian capital market. Of the total 51 firms listed, our sample represents $96 \%$ of financial firms listed on the Nigeria Stock Exchange. We are confident that our findings can be extended to other firms in the sector. Once the companies were identified we manually extracted the data with respect to each of our variables. For Corporate Social Responsibility spending on education and ICT, we ascertain if the firm indicated in the annual report the actual amount spent on these activities. If they do, we assign the value of 1 and 0 for otherwise. Women on board was measured using the exact number of female representations on board. If the CEO was female, we assign the value of 1 and 0 for otherwise. The size of the board was captured using the total number of directors on board.

\section{RESULTS}

Table 1 reports the descriptive statistics of our sample firm. The dependent variables, CSRict and CSRedu, are dummy variables which are set to 1 when there is a presence of CSR spending on ICT and presence of CSR spending on Education and 0 for otherwise. Mean values of 0.125 and 0.589 respectively implies that on average $12.5 \%$ of the sample firm spent money on CSR activities on ICT and $58.9 \%$ spent money on CSR activities on education respectively. A maximum of five women are on board (Female director) of the sample firm, representing $19.4 \%$ on average of women on board between 2016 to 2019. We further broke down the number of female directors into categories. Of the $19.4 \%$ of women on board there is an average of $31.95 \%$ with one woman on board (one female dir), $8 \%$ with two women on board (two female dirs), $23.3 \%$ with three women on board (three female dirs), 13.5 with four women on board (four female dirs) and $3 \%$ with five women on board (five female dirs). $11.1 \%$ of the sample firm have female CEOs. There is an average of 9.8 directors on board (Board Size) the minimum being 3 and maximum being 20 directors.

Hypothesis 1 and 2 predict board composition, indicated by the proportion of women on board and corporate CSR spending on educational activities and ICT activities respectively. Hence, we 
conducted a panel regression analysis presented in table 2. We regressed the dependent variables, CSRict and CSRedu against the explanatory variables, board composition in column 1 and 2 respectively. In column 1, board having only one female director is positive and significant to CSR spending on education at $5 \%$ level. The result infers that the presence of having one female on board determines CSR spending on educational activities. Also, board size is positive and significant to CSR spending on education at $1 \%$ level. This implies that a large board size is a precursor to CSR spending on educational activities by $6.0 \%$. In column 2 , presence of at least a female director is positively and significant to CSR spending on ICT at $10 \%$ level. The representation of three, four and five female directors on board is negatively and significantly related to CSR spending on ICT at $10 \%$, $5 \%$ and $10 \%$ respectively. This implies that increase in women representation on board decreases chance of CSR spending on ICT activities by $29.1 \%, 50.3 \%$ and $58.2 \%$ respectively. Board size is positively and significant to CSR spending on ICT at $1 \%$ level. Our result suggest that higher board size promotes CSR spending on ICT activities by $3.9 \%$.

Hypothesis 3 and 4 predict that a board with more than one woman is more likely to be involved in corporate CSR spending on educational activities than a board with no women. To this end we conducted a binary logistic regression analysis to check for the likelihood effects of the number of women on board with reference to a board with no woman and CSR spending on education and ICT. The result is presented in table 3 . In column 1, we regress CSRedu on one woman on board, three women on board, four women on board and five women on Board and found that the estimated odds ratio is positive and significant at $1 \%, 1 \%, 1 \%$ and $5 \%$ level respectively. This indicates that there is a likelihood of up to $4.533,5.333,8.000,10.000$ times of firm's spending on CSR education when there is one woman on board, three women on board, four women on board and five women on board respectively. In column 2, we regress CSRict on one woman on board, two women on board, three women on board, four women on board and five women on Board and obtained odds ratios of 1.256, $0.750,2.000,1.588,1.800$ respectively. None is statistically significant. This indicates that the number of women on board is not significant to the likelihood CSR spending on ICT activities.

Table 1: Descriptive Statistics.

\begin{tabular}{l|l|c|c|c|c}
\hline \multicolumn{1}{c|}{ Variables } & \multicolumn{1}{c|}{ Definition } & Mean & $\begin{array}{c}\text { Std. } \\
\text { Dev }\end{array}$ & Min & Max \\
\hline CSRict & Presence of CSR spending on ICT & 0.125 & 0.332 & 0 & 1 \\
\hline CSRedu & Presence of CSR spending on Education & 0.589 & 0.493 & 0 & 1 \\
\hline Female director & Number of Women Directors on the Board & 1.939 & 1.514 & 0 & 5 \\
\hline One female Dir & There is at least one female director on the Board & 0.319 & 0.468 & 0 & 1 \\
\hline Two female Dirs & There are at least two female directors on the Board & 0.080 & 0.272 & 0 & 1 \\
\hline Three female Dirs & There are at least three female directors on the Board & 0.233 & 0.424 & 0 & 1 \\
\hline Four female Dirs & There are at least four female directors on the Board & 0.135 & 0.343 & 0 & 1 \\
\hline Five female Dirs & There are at least five female directors on the Board & 0.037 & 0.189 & 0 & 1 \\
\hline Female CEO & 1 if the CEO is female and 0 if otherwise & 0.111 & 0.315 & 0 & 1 \\
\hline Board Size & Number of directors on the board & 9.855 & 3.273 & 3 & 20 \\
\hline
\end{tabular}

Table 2: Panel Regression Results.

\begin{tabular}{l|c|c}
\hline \multicolumn{1}{c|}{ Dependent Variable } & CSRedu & CSRict \\
\hline Female director & 0.023 & $0.093^{*}$ \\
& $(0.30)$ & $(1.62)$ \\
\hline One female Dir & $\mathbf{0 . 2 8 3 ^ { * * }}$ & -0.926 \\
& $(2.42)$ & $(-1.05)$ \\
\hline Two female Dirs & 0.100 & -0.149 \\
& $(0.49)$ & $(-0.97)$ \\
\hline Three female Dirs & 0.143 & $-0.291^{*}$ \\
& $(0.61)$ & $(-1.64)$ \\
\hline Four female Dirs & 0.081 & $-\mathbf{0 . 5 0 3}^{* *}$
\end{tabular}




\begin{tabular}{l|c|c} 
& $(0.27)$ & $(-2.18)$ \\
\hline Five female Dirs & 0.018 & $-0.582^{*}$ \\
& $(0.05)$ & $(-1.91)$ \\
\hline Female CEO & 0.083 & -0.106 \\
& $(0.72)$ & $(-1.21)$ \\
\hline Board Size & $\mathbf{0 . 0 6 0 ^ { * * * }}$ & $\mathbf{0 . 0 3 9 ^ { * * * }}$ \\
& $(4.42)$ & $(3.77)$ \\
\hline Constant & -0.158 & -0.216 \\
& $(-1.16)$ & $(-2.1)$ \\
\hline Observations & 151 & 151 \\
\hline R-squared & 0.236 & 0.158 \\
\hline Adjusted R-squared & 0.193 & 0.110 \\
\hline Root MSE & 0.434 & 0.327 \\
\hline
\end{tabular}

Table 2 shows coefficients of Presence of CSR spending on ICT and Education on measures of female representation on board. ${ }^{*},{ }^{* *}$, and ${ }^{* * *}$ indicate significance at $10 \%, 5 \%$, and $1 \%$ levels, respectively. t-statistic are in parentheses. Significant results (at $5 \%$ level or better) are in boldface. All equations include a constant term.

Table 3: Binary Logistic Regression Results.

\begin{tabular}{|c|c|c|}
\hline Dependent Variable & CSRedu & CSRict \\
\hline No woman on Board & Reference Category & Reference Category \\
\hline One female Dir & $\begin{array}{c}\mathbf{4 . 5 3 3}^{\star \star \star} \\
(3.05)\end{array}$ & $\begin{array}{l}1.256 \\
(0.30) \\
\end{array}$ \\
\hline Two female Dirs & $\begin{array}{l}1.714 \\
(0.80) \\
\end{array}$ & $\begin{array}{c}0.750 \\
(-0.24) \\
\end{array}$ \\
\hline Three female Dirs & $\begin{array}{c}\mathbf{5 . 3 3 3}^{* * *} \\
(3.04) \\
\end{array}$ & $\begin{array}{l}2.000 \\
(0.91) \\
\end{array}$ \\
\hline Four female Dirs & 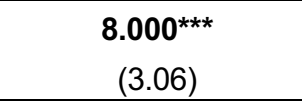 & $\begin{array}{l}1.588 \\
(0.53)\end{array}$ \\
\hline Five female Dirs & $\begin{array}{c}10.000^{* *} \\
(1.98)\end{array}$ & $\begin{array}{l}1.800 \\
(0.47)\end{array}$ \\
\hline Log likelihood & -90.297875 & -58.29913 \\
\hline Number of observations & 151 & 151 \\
\hline LR chi2(5) & 18.55 & 1.49 \\
\hline Prob > chi2 & 0.0023 & 0.9143 \\
\hline Pseudo R2 & 0.0931 & 0.0126 \\
\hline
\end{tabular}

Table 3 shows the odds ratio of Presence of CSR spending on ICT and Education on measures of female representation on board. * ${ }^{* *}$, and ${ }^{* * *}$ indicate significance at $10 \%, 5 \%$, and $1 \%$ levels, respectively. t-statistic are in parentheses. Significant results (at $5 \%$ level or better) are in boldface. All equations include a constant term

\section{CONCLUSIONS}

Coronavirus recrudescent revealed a vital state of affairs on how corporates have been responsive to genuine and authentic CSR activities in addressing economic and social challenges. This study contributes to literature on gender board composition and CSR spending on education and ICT activities prior Covid-19. Using dataset of listed financial firms from 2015-2019. We find significant and positive evidence that board with more than one woman are involved in educational CSR activities than board with no woman. The result suggests that female representation on board have more effects when they are at least three. This supports the critical mass theory by Kanter (1977), that infers 
that the presence of women on board is more effective when they move from a fringe presence to a substantial number. Surprisingly, the view that firms with female directors tends to be easily disposed to invest more in innovative projects by [18] is not supported in this study. Being that the effect of women on board is negative and significant when it comes to participation in CSR activities on ICT. We also found that a maximum of five women were on a board of twenty directors. This indicate that women to directors' ratio is one to four in a best-case scenario. The representation of women as CEOs is still not balanced, only $11.1 \%$ of the sample firm have female CEOs. Also, having a female as the CEO do not significantly contribute to CSR spending on education and ICT. Board size is positively and significant to CSR spending on education and ICT. Our findings suggest that the number of women on board and not just the mere representation of women on board is fundamental to CSR spending on education.

\section{ACKNOWLEDGEMENTS}

The Authors are grateful to Covenant University for providing funding for the article publication

\section{REFERENCES}

[1] World Bank, Ending Learning Poverty: What will it take. 2019.

[2] World Bank, "Connecting for Inclusion: Broadband Access for All," 2019.

[3] A. Okafor, M. Adusei, and B. Ngozi, "Corporate social responsibility and financial performance: Evidence from U . S tech fi rms," vol. 292, 2021, doi: 10.1016/j.jclepro.2021.126078

[4] M. S. Shabbir and O. Wisdom, "The relationship between corporate social responsibility, environmental investments and financial performance: evidence from manufacturing companies," Environ. Sci. Pollut. Res., vol. 27, no. 32, pp. 39946-39957, 2020, doi: 10.1007/s11356-02010217-0

[5] O. Kehinde Olaide, E. K. Worlu Rowland, M. B. Deborah, and O. C. Abayomi, "The effect of corporate social responsibility on the profitability of nigerian banks (A comparative study of first bank and eco bank)," in Proceedings of the 30th International Business Information Management Association Conference, IBIMA 2017 - Vision 2020: Sustainable Economic development, Innovation Management, and Global Growth, 2017, doi: 10.5171/2018.379009

[6] A. H. Eagly and L. L. Carli, "The female leadership advantage: An evaluation of the evidence," Leadersh. Q., 2003, doi: 10.1016/j.leaqua.2003.09.004

[7] K. B. Backhaus, B. A. Stone, and K. Heiner, "Exploringthe Relationship Between Corporate Social Performance and Employer Attractiveness," Bus. Soc., 2002, doi: $10.1177 / 0007650302041003003$

[8] Y. Liu, Z. Wei, and F. Xie, "Do women directors improve firm performance in China?," J. Corp. Financ., 2014, doi: 10.1016/j.jcorpfin.2013.11.016

[9] F. A. Gul, B. Srinidhi, and A. C. Ng, "Does board gender diversity improve the informativeness of stock prices?,” J. Account. Econ., 2011, doi: 10.1016/j.jacceco.2011.01.005

[10] A. Périlleux and A. Szafarz, "Women Leaders and Social Performance: Evidence from Financial Cooperatives in Senegal," World Dev., 2015, doi: 10.1016/j.worlddev.2015.05.011

[11] M. Harjoto, I. Laksmana, and R. Lee, "Board Diversity and Corporate Social Responsibility," J. Bus. Ethics, 2015, doi: 10.1007/s10551-014-2343-0

[12] S. Bear, N. Rahman, and C. Post, "The Impact of Board Diversity and Gender Composition on Corporate Social Responsibility and Firm Reputation," J. Bus. Ethics, 2010, doi: 10.1007/s10551010-0505-2

[13] L. Rodríguez-Ariza, B. Cuadrado-Ballesteros, J. Martínez-Ferrero, and I. M. García-Sánchez, "The role of female directors in promoting CSR practices: An international comparison between family and non-family businesses," Bus. Ethics, 2017, doi: 10.1111/beer.12140

[14] R. B. Adams and D. Ferreira, "Women in the boardroom and their impact on governance and performance," J. financ. econ., 2009, doi: 10.1016/j.jfineco.2008.10.007 
[15] M. Ararat and B. B. Yurtoglu, "Female directors, board committees, and firm performance: Timeseries evidence from Turkey," Emerg. Mark. Rev., 2020, doi: 10.1016/j.ememar.2020.100768

[16] T. Nguyen, S. Locke, and K. Reddy, "Does boardroom gender diversity matter? Evidence from a transitional economy," Int. Rev. Econ. Financ., 2015, doi: 10.1016/j.iref.2014.11.022

[17] J. Sarkar and E. Selarka, "Women on board and performance of family firms: Evidence from India," Emerg. Mark. Rev., 2020, doi: 10.1016/j.ememar.2020.100770

[18] J. Chen, W. S. Leung, and K. P. Evans, "Female board representation, corporate innovation and firm performance," J. Empir. Financ., 2018, doi: 10.1016/j.jempfin.2018.07.00

[19] O. Emmanuel, U. Uwuigbe, O. Teddy, I. Tolulope, and G. A. Eyitomi, "Corporate diversity and corporate social environmental disclosure of listed manufacturing companies in Nigeria," Probl. Perspect. Manag., vol. 16, no. 3, pp. 229-244, 2018, doi: 10.21511/ppm.16(3).2018.19

[20] Y. Chauhan and D. K. Dey, "Do female directors really add value in Indian firms?," J. Multinatl. Financ. Manag., 2017, doi: 10.1016/j.mulfin.2017.10.005 